\title{
University-industry cooperation: A systematic literature review and research agenda
}

\author{
Carla Mascarenhas ${ }^{1, *}$, João J. Ferreira ${ }^{2}$ and Carla Marques ${ }^{3}$
}

${ }^{1}$ Doctoral Candidate in Management, University of Beira Interior and CETRAD-Research Unit, Portugal, Portugal, ${ }^{2}$ Associate Professor in Management, University of Beira Interior and NECE-Research Unit in Business Sciences, Portugal and ${ }^{3}$ University of Trás-os-Montes and Alto Douro and CETRAD-Research Unit, Portugal

*Corresponding author. Email: carlam@utad.pt

\begin{abstract}
As university-industry cooperation is associated with the transfer of knowledge and technology, this collaboration is an extremely important field of study for the world's economies that helps companies become more competitive. The present research, thus, sought to explore and analyse the literature related to university-industry cooperation, using a co-citation analysis. This study's objectives were to (1) identify the main co-cited references and the groups (i.e. clusters) they form and (2) discuss the challenges this literature presented in the study of university-industry cooperation. The articles reviewed were obtained with a search of the ISI's Web of Science and were submitted to a bibliometric analysis using VOSviewer software. This systematic literature review revealed that companies are increasingly focused on cooperation with universities. The results include four clusters, namely, (1) Absorption Capacity, Knowledge and Competitiveness in University-Industry Relations, (2) Impact of Knowledge Spill-overs on University-Industry Relations, (3) Strategic Alliances for Industry Innovation, and (4) University-Industry Cooperation. This study thus contributes to a greater and more detailed understanding of the production flow, scientific practices, and trends in this new and stimulating field of research.
\end{abstract}

Key words: strategy; innovation; research; university-industry cooperation; systematic literature review.

\section{Introduction}

The importance of knowledge exchange among public institutionsmostly universities—and private organisations has long been widely recognised as a significant phenomenon. A glance at the economies and innovation levels of industrialised countries reveals that their efficiency is due to the production of knowledge and its use in industries, thereby achieving competitive advantages in global markets. Thus, cooperation between universities and industries can facilitate knowledge transfer and stimulate the production of new knowledge and technology (Leydesdorff and Meyer 2006; Enkel et al. 2009; Freitas et al. 2013a). Cooperation between Universities and Industry includes collaborative research, research contracts, or scientific consultancy, the results of which are put into practice-in a process comparable to technology transfer for commercialisation purposes-by more researchers (Perkmann et al. 2013; Leydesdorff et al. 2014; Berbegal-Mirabent et al. 2015).

Companies are constantly under pressure to change, which makes regional innovation systems important to both regional economies and national competitiveness (Anderson et al. 2011). The effectiveness of research and development (R\&D) investment depends on interactions between local companies and institutions in the scientific and technological system. When this interaction becomes progressively more active, $\mathrm{R} \& \mathrm{D}$ investment by companies, universities and research institutes has a stronger effect on the construction of regional innovation systems (Etzkowitz and Klofsten 2005; Jiao et al. 2016). Innovation—and its contribution to the economy-increasingly appears high on current government agendas. The growing numbers of innovation actors in Europe, for instance, are largely due to the support provided by European structural funds, which have decentralised innovation by facilitating regional development (Kaiser and Prange 2004; Heringa et al. 2016). The European Commission (2016), for example, relies on its Horizon 2020 plan to support innovation, thereby making Europe the largest global innovation hub today (European Commission 2017).

Some studies have already carried out systematic literature review (SLR) focused on university-industry cooperation. However, they have focused only on the types of links between universities and/or companies and open innovation (Perkmann and Walsh 2007) or technology transfer (Agrawal 2001; Geuna and Muscio 2009) or on the flow of university research and entrepreneurship (Rothaermel et al. 2007). In addition, so far, the literature does not include any SLRs on the subject matter under study that have used bibliometric techniques, so, with this study, we sought to fill this gap in the area 
of innovation and research strategy by taking into account university-industry cooperation.

This article appealing to the analysis of co-citations allowed us to obtain citation networks composed by cluster. This citation network is a collection of articles of a specific research specialty or paradigm that allowed us to understand the most important areas when studying University-Industry cooperation (Garfield 2001).

This research-in addition to contributing an SLR focused on cooperation between universities and industry-presents a future agenda for research to answer the questions raised by this review. This study made it possible to explore and describe the existing scientific literature on innovation strategies in university-industry relations. Hence, this study aims to: (1) identify the main co-cited references and the groups they form (i.e. clusters) and (2) discuss the challenges this literature presents (i.e. opportunities and difficulties) in the study of innovation strategies in university-industry relationships (i.e. research opportunities in this area).

A systematic approach was followed in the literature review, including a rigorous protocol and definition of steps in the research and analysis of the literature based on scientific articles published in the Web of Science. The 294 articles identified related to innovation strategies in university-industry relationships were submitted to a bibliometric analysis.

This article is structured as follows: Section 2 provides the methodological approach used in the SLR. The results are then discussed. Conclusions and the future research agenda are presented in the last section.

\section{Literature review}

\subsection{Innovation R\&D}

Business innovation is strongly linked to R\&D contracts, suppliers, customers, and competitors. However, each type of R\&D collaboration differs in terms of the breadth of new knowledge provided to companies and the ease of access to this new knowledge, resulting in a different impact on product innovation (Rampersad et al. 2010; Un et al. 2010). As universities have taken on the mission of research and technological development, the role they play in this process is essential (Ranga et al. 2016). At least two major trends can be identified that affect the future role of universities: (1) a shift to an increasing dependence of economies on knowledge production and (2) an attempt to identify and shape future trends in the production of knowledge and its implications for society. A shift is occurring from production economies to the socio-economic processes of contemporary innovation systems, with universities becoming part of a new knowledge infrastructure (Etzkowitz et al. 2000; Etzkowitz and Leydesdorff 2000). In the context of current knowledge-based innovation and the associated role played by knowledge-based networks, the model of universities centred around functioning as a vehicle for technology transfer has become organisationally and institutionally more complex. However, in essence, universities serve as a channel through which the exchange and exploitation of knowledge becomes more effective (Doloreux and Mattson 2008; Estrada et al. 2016). The network created for the development of knowledge and innovation is often supported by funding programmes, serving as the engine of leveraged innovation and its transfer to corporate environments (Ning et al. 2016; Zhou et al. 2016). The effectiveness of $\mathrm{R} \& \mathrm{D}$ investment is conditioned by interactions between local producers and users of knowledge. When these connections become increasingly active, the R\&D investment of companies, universities, and research institutes has a stronger effect on the construction of regional innovation systems. Overall, the interactions between local producers and knowledge users have an inverted U-shaped relationship with the construction of regional innovation systems (Jiao et al. 2016).

\subsection{Strategic alliances and technology transfer}

A combination of knowledge management and strategic management theories provides a framework for understanding the imperatives of collaborative research partnerships, particularly those involving governments, universities, and industry stakeholders (Freitas et al. 2013b). This collaboration is facilitated by the sharing of knowledge across organisational boundaries, which promotes the formation of relationships of trust and builds social capital for greater cooperation. In addition, these partnerships are a vehicle for accelerating organisational learning and for coordinating crossorganisational 'innovation communities'. Understanding the nature, process, and content of these collaborative research and technological development processes can provide strategic insights into how best to design government policies (McKeever et al. 2014). Governments and industries, in particular, can learn from past experiences in order to design intelligent trans-organisational knowledge interfaces that ensure knowledge sharing occurs across organisational boundaries (Carayannis et al. 2000; Segarra-Blasco and Arauzo-Carod 2008). With regard to existing partnerships between universities and industries, a positive two-way link exists between the intensity of relationships and the level of tangible results generated. Although the size of the organisations and the duration of their relationships do not significantly affect these dynamics, companies' geographic proximity to university research centres has a significant effect, as this is crucial for the choice of which partnerships to create or company innovation strategies to apply (Santoro 2000).

\subsection{Knowledge transfer and intellectual property}

Knowledge transfer between organisations has become a critical resource for the survival and growth of any business. In order to obtain external knowledge, companies seek to create different partnerships and governance strategies and to contextualise themselves on an international level (Santoro and Chakrabarti 2002; Muscio et al. 2013). One way of gaining knowledge is by going to universities, which offer a wide variety of channels through which knowledge and technology can be transferred between universities and industries. The choice of which channels to use depends on the disciplines of origin, characteristics of the underlying knowledge and characteristics of the researchers involved in the production process, and the use of this knowledge (i.e. individual characteristics). In addition, choices are affected by the environment in which knowledge is produced and used (i.e. institutional characteristics) (Bekkers and Bodas Freitas 2008; Kim 2013). Technology Transfer Offices (TTOs) and Industrial Liaison Offices are primarily responsible for establishing university-industry partnerships. R\&D contracts exemplify the indirect mechanisms through which companies and universities collaborate with common earnings (Berbegal-Mirabent et al. 2015). Strategies focused on monopolising profits through legal mechanisms and controlling key resources may work in some industrial settings but may hinder innovation in others, leaving promising technologies unexplored. In this way, more open approaches to the management of intellectual property-combined with proposals that emphasise cognitive and socio-political legitimacy-can lead to a more effective diffusion of these innovations (Hall et al. 2014). 
Overall, the academic performance of universities is generally valued much more highly than advancements obtained by licensing (Cohen et al. 2002; Perkmann et al. 2011).

\subsection{Entrepreneurial universities and the triple helix}

The neo-institutional model of higher education institutions has been conceptualised, over the last few decades, as 'entrepreneurial universities' (Clark 1998; Etzkowitz 2002, 2003; Lawton Smith and Leydesdorff 2012). Regions (i.e. 'triple helix regional spaces') are then considered endowed with universities that can be optimised to fulfil their third mission through additional incentives for higher education and internationally oriented research (Venditti et al. 2013). In line with the growth of a global knowledge economy, many European countries have implemented reforms of their national research systems to increase the commercialisation of research and the transfer of knowledge from university to industry. The focus of policymakers has shifted to the third mission of universities so that, beyond the basic functions of teaching and researching, universities are required to contribute to society through the creation, transfer, and exchange of knowledge and technologies (Bellucci et al. 2016). Consequently, many universities have evolved from traditional institutions characterised as an 'ivory tower' to an 'entrepreneurial university' with strong links to industries and a more active role in promoting knowledge transfer to these industries (Clark 1998; Etzkowitz 1983; Bercovitz and Feldman 2007; Rothaermel et al. 2007). The triple helix model of academia-industry-government relations is an emerging entrepreneurial paradigm in which universities play an enhanced role in technological innovation. Governments have encouraged this academic transformation as an economic development strategy, which also reflects changes in the relationship between knowledge producers and users (Etzkowitz et al. 2000; Etzkowitz and Leydesdorff 2000; Ranga and Etzkowitz 2013).

\section{Methodology}

A systematic review of the available academic research was carried out on the topic of university-industry cooperation. The research was carried out using VOSviewer software version 1.6.5 in order to construct and display bibliometric maps, as well as to identify clusters and their reference networks (van Eck and Waltman 2010; Waltman et al. 2010; Perianes-Rodriguez et al. 2016).

The search for relevant papers, articles, proceedings, and reviews was carried out in the Thomson Reuters International Scientific Indexing (ISI) database with no temporal restrictions. The search focused on the Social Science Citation Index of the Science Citation Index Expanded and the Arts and Humanities Citation Index for all journals of these indexes. In spite of Scopus coverage of a wider journal range, it is currently limited to recent articles (published after 1995) compared with Web of Science. Since WOS is the oldest citation database, it has strong coverage with citation data and bibliographic data which goes back to 1900 (Boyle and Sherman 2006). Also, Thomson Reuters ISI is made of several important databases: Social Science Citation Index, Science Citation Index Expanded, Arts and Humanities Citation Index, and Book Citation Index but includes also several databases of proceedings from various fields (Gasparyan et al. 2013). We used the keywords "strateg" and innovation', 'academia', 'high" education*', and 'industr"' as a topic and 'universit"' in titles, which resulted in 294 documents. The search was performed on 26 January 2017. The research protocol is displayed in Fig. 1.

\section{Results}

Fig. 2 shows the evolution of the number of publications and citations of the 294 documents from 1993 to 2016. Citations have been increasing significantly, reaching a maximum number in 2015 of 565 citations. As for the number of publications, the first article appeared in 1993, and, until 2007, only a few articles were published annually in the area under study. The number of publications reached its highest point in 2012 with forty-one publications.

Of the 294 documents found, 172 (58.50 per cent) do not have any citations and 66 (22.45 per cent) have less than ten citations. Table 1 lists the ten most cited articles.

The most cited articles focus on topics as diverse as the triple helix model (Etzkowitz et al. 2000), factors that influence the links between universities and companies, the innovation strategies of companies (Santoro and Chakrabarti 2002; Laursen and Salter 2004; Veugelers and Cassiman 2005; Bercovitz and Feldman 2007; Perkmann and Walsh 2007), and the transfer of knowledge and technology (Agrawal 2001, 2006; Shane 2002; Geuna and Muscio 2009). Most of the articles present quantitative studies, with some using mixed methodologies that combine case studies with quantitative methods.

\subsection{Co-citations of references}

In order to identify the tendencies of the literature on university-industry cooperation that is, how research on this topic is divided into clusters, an analysis of co-citations of references was carried out based on articles with at least ten co-citations, which resulted in four clusters (see Fig. 3) involving fifty-eight publications. The clusters are (1) Absorption Capacity, Knowledge and Competitiveness in University-Industry Relations, (2) Impact of Knowledge Spillovers on University-Industry Relations, (3) Strategic Alliances for Industry Innovation, and (4) University-Industry Cooperation.

\subsubsection{Cluster one: Absorption Capacity, Knowledge and} Competitiveness in University-Industry Relations

Table 2 presents the top five most co-cited authors of cluster one.

The capacity to innovate is upon determined by the companies' absorption capacity, which depends on the firms' previous level of knowledge (Cohen and Levinthal 1990). In their quest for innovation, companies seek, in most cases, universities. However, there are several obstacles that must be overcome before this cooperation can take place.

According to Bruneel et al. (2010), there are two types of barriers: (1) those related to differences in industry and university orientations or 'guidance barriers' and (2) barriers related to intellectual property disputes and university administration or 'transactionrelated barriers'. Regarding both internal and external university policies, the authors' state that the entities involved need to find simple and effective mechanisms for the management and monitoring of university-industry interactions.

Nevertheless, as pointed by George et al. (2002), the links between universities and industries are important for the development and transfer of new technologies, as well as for the creation of new products. These links are also an important source of revenue and new knowledge for some universities. Connections with leading universities also serve other important purposes, namely, improving the reputation of companies and increasing their access to important sources of innovation. Business links with universities-particularly those with a strong research mission—can be strategically beneficial to biotechnology companies. 


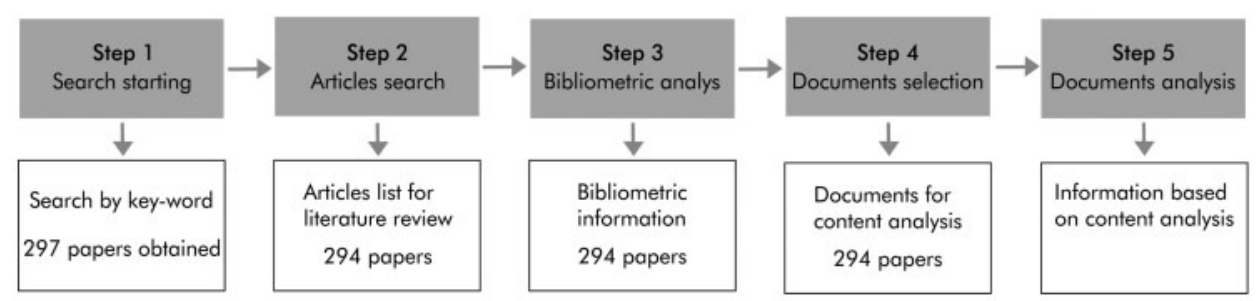

Figure 1. Search protocol.

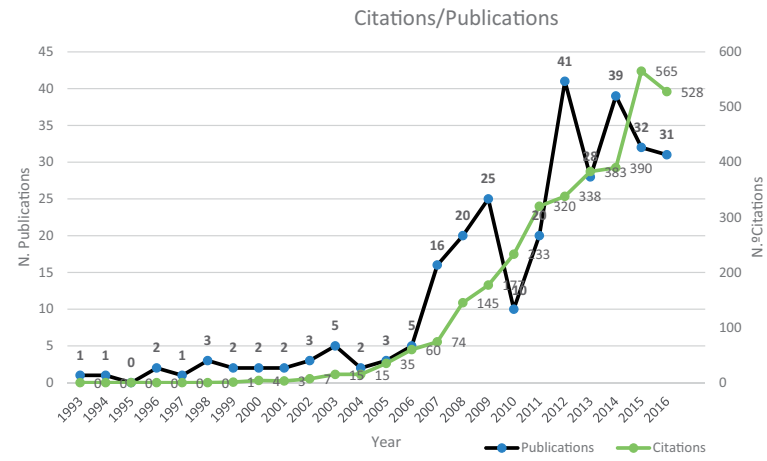

Figure 2. Total publications and citations by year.

As Dasgupta and David (1994) showed the characteristics and norms of institutions, open science and other modes of scientific inquiry are also important factors for industry-university relations. These authors concluded that open science only promotes academic reputations. They examined policy measures and institutional reforms seeking to promote the transfer of knowledge between open science and research and commercial development. The conclusion drawn was that no economic force automatically ensures the dynamic efficiency of the organisational interactions of open science researchers and industries.

Based on review on absorption capacity, Zahra and George (2002) identified 'activation triggers' or mechanisms that encourage or impel companies to respond to specific internal and external stimuli. Events may take the form of internal organisational crises that force companies to redefine their strategy. Another element related to absorption capacity refers to the mechanisms of social integration used by companies to facilitate the sharing and diffusion of knowledge within these organisations, thereby contributing to the assimilation of knowledge. Certain organisational structures, spaces, and formal policies can broaden the exchange of knowledge, so these mechanisms could be positively related to companies' absorptive capacity.

\subsubsection{Cluster two: The Impact of Knowledge Spillovers on} University-Industry Interactions

Table 3 presents the articles belonging to the second cluster defined. These are closely associated with the spillover of knowledge and its effect on interactions with companies.

As Cohen et al. (2002) stated, public research is critical to industrial R\&D in a small number of companies and affects the production of many industries. University research contributes with new $\mathrm{R} \& \mathrm{D}$ projects, as well as to the completion of existing projects. The main channels through which research has an impact on industrial $\mathrm{R} \& \mathrm{D}$ include reports, public conferences and meetings, informal information exchange, and consultancy. After controlling for type of industry, the influence of public research on industrial R\&D is disproportionately greater for large and start-up companies and firms investing more in their absorption capacity.

According to Meyer-Krahmer and Schmoch (1998), cooperation between industrial companies and universities has increased considerably in recent years, but the pattern of interaction in different technological fields varies. In addition, the solution of technical problems remains a major concern of industries. The exchange of knowledge in techno-scientific communities is a crucial element in the interactions between universities and businesses. In particular, the combination of a long-standing culture of cooperation and economic success in a given industry can be the key to the success of a university's partnership with an industry.

Opposing to expectations in the university's partnership with an industry patenting is not representative of the direction and impact of knowledge generated by universities. Based on qualitative and quantitative data obtained from Massachusetts Institute of Technologies Departments of Mechanical Engineering and Electrical Engineering, Agrawal and Henderson (2002) show that patenting is a minority activity since publication rates far outweigh patent registration fees. The results also suggest that the registration of patents is not representative of patterns neither of knowledge transfer nor of companies' demand for knowledge.

However, the statistical results of Jaffe's (1989) study provide evidence that businesses' patent activity responds positively to the commercial spillovers of university research. Patent activity increases not only the R\&D investment of companies but also the research expenses incurred by universities. According to the cited author, the extent to which university research spillovers serve as a catalyst for innovative business activities can be determined by using the direct measure of innovative activity in the proposed model, as introduced by the relevant equation.

One of the main problems in industry-university cooperation is the time lag between investment in recent research projects and the industrial use of results. Mansfield (1991) sought to estimate the social rate of return of academic research, which he considers of interest to policymakers focusing on science and technology, as well as, to economists and others who study the process of technological change. The results suggest that about one-tenth of the new products and processes marketed from 1975 to 1985 in the information processing, electrical equipment, chemical, instrument, medicine, metal, and petroleum industries could not have been developed-without substantial delays-with no academic research. Based on the cited research, the average time lag between completion of relevant academic research and the first commercial introduction of innovations is about 7 years and tends to be longer for large firms than for small ones.

\subsubsection{Cluster three: Strategic Alliances for Business Innovation}

This cluster includes authors who focus on business innovation strategy and alliances with the institutions in which this innovation occurs (Table 4). 


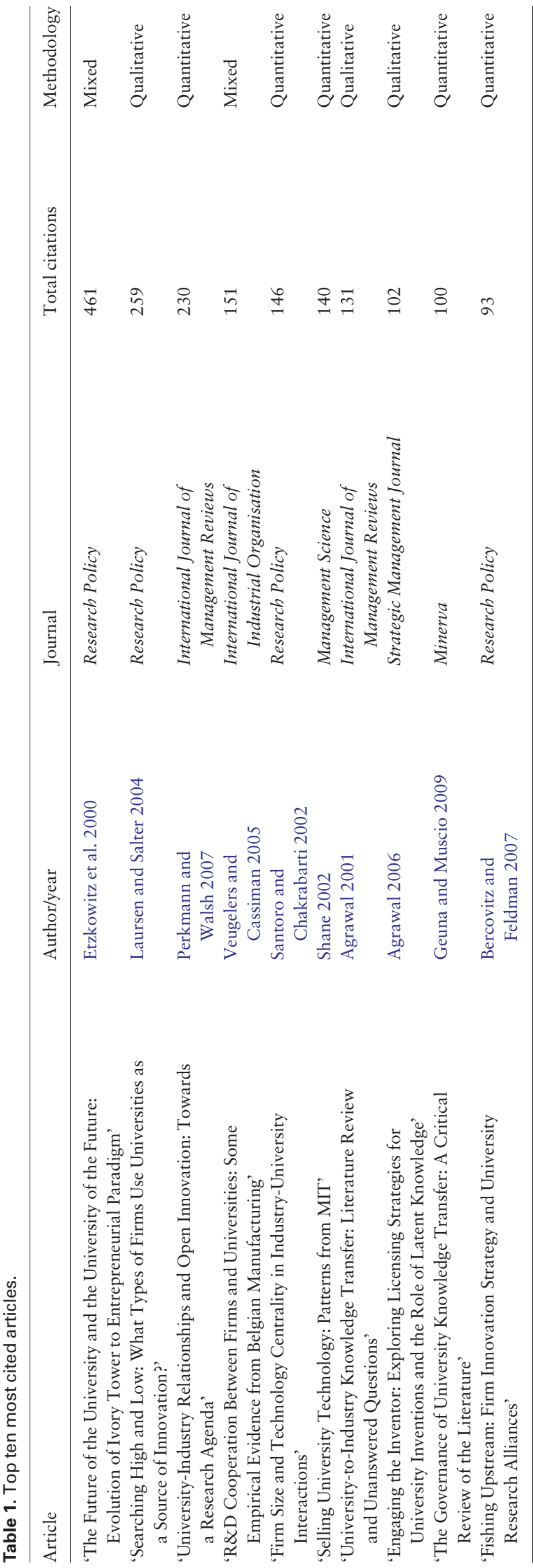

This cluster includes authors who focus on business innovation strategy and alliances with the institutions in which this innovation occurs.

The alliances for business innovation have some determinants related to the research cooperation between firms and public research entities. According to Fontana et al. (2006), there are two main phenomena. First, the propensity to generate an agreement with an academic partner depends on the 'absolute size' of the industrial partner. Secondly, the opening up of firms to the external environment-measured by their willingness to sign on research partners-significantly affects the development of R\&D projects. The acquisition of knowledge by sorting through publications and getting involved in public policies positively affects the probability of signing a contract with a public research entity but not the number of R\&D projects developed.

For Cohen and Levinthal (1989), R\&D not only generates new information but also increases companies' ability to assimilate and exploit existing information. The cited authors suggest that the recognition of this second role of R\&D indicates that the ease and type of learning within companies affects both R\&D spending and conditions the likelihood and conditions of research. Contrary to the usual findings on this relationship, intra-industry spillovers can encourage industries' R\&D investment. Even though R\&D obviously manages innovation, R\&D also develops companies' ability to identify, assimilate, and exploit surrounding knowledge, that is, the learning or absorption capacity of firms.

Management strategies related to the decision to integrate innovation and collaboration are a particularly important factor. Teece (1986) reveals that, when innovation is easy to imitate, profits can be transferred to the owners of certain complementary assets rather than to the inventors. This is due to the need, in some cases, for innovative companies to establish a prior position in these complementary assets. The same phenomenon happens with companies and their innovative products that are not yet positioned in the market.

Santoro and Chakrabarti's (2002) multi-method field study indicated that larger, more mechanistic firms, especially those in resource-intensive industries, use knowledge transfer and researchsupport relationships to build competencies in non-essential technology areas. In contrast, smaller, more organic enterprises-particularly those in highly technological industries-are more focused on solving problems in key technological areas through technology transfer and cooperative research relationships.

Laursen and Salter (2004), in turn, examined the factors influencing businesses' demand for university research and the ways they extract innovative activities. The cited authors' results suggest that companies that adopt 'open' research strategies and invest in R\&D are more likely to cooperate with universities and to achieve satisfactory results.

\subsubsection{Cluster four: Universities in Cooperation with Industry}

This cluster involves authors who have focused on the relationship between university and industry. In particular, these articles discuss the types of cooperation present in academic entrepreneurship, that is, entrepreneurial universities and their cooperation mechanisms (see Table 5).

Etzkowitz and Leydesdorff (2000) explain innovation and university-industry links using the triple helix model. There are at least two major trends that affect the future role of entrepreneurial universities. The first is a shift to an increasing dependence of economies on the production of knowledge and attempts to identify and 


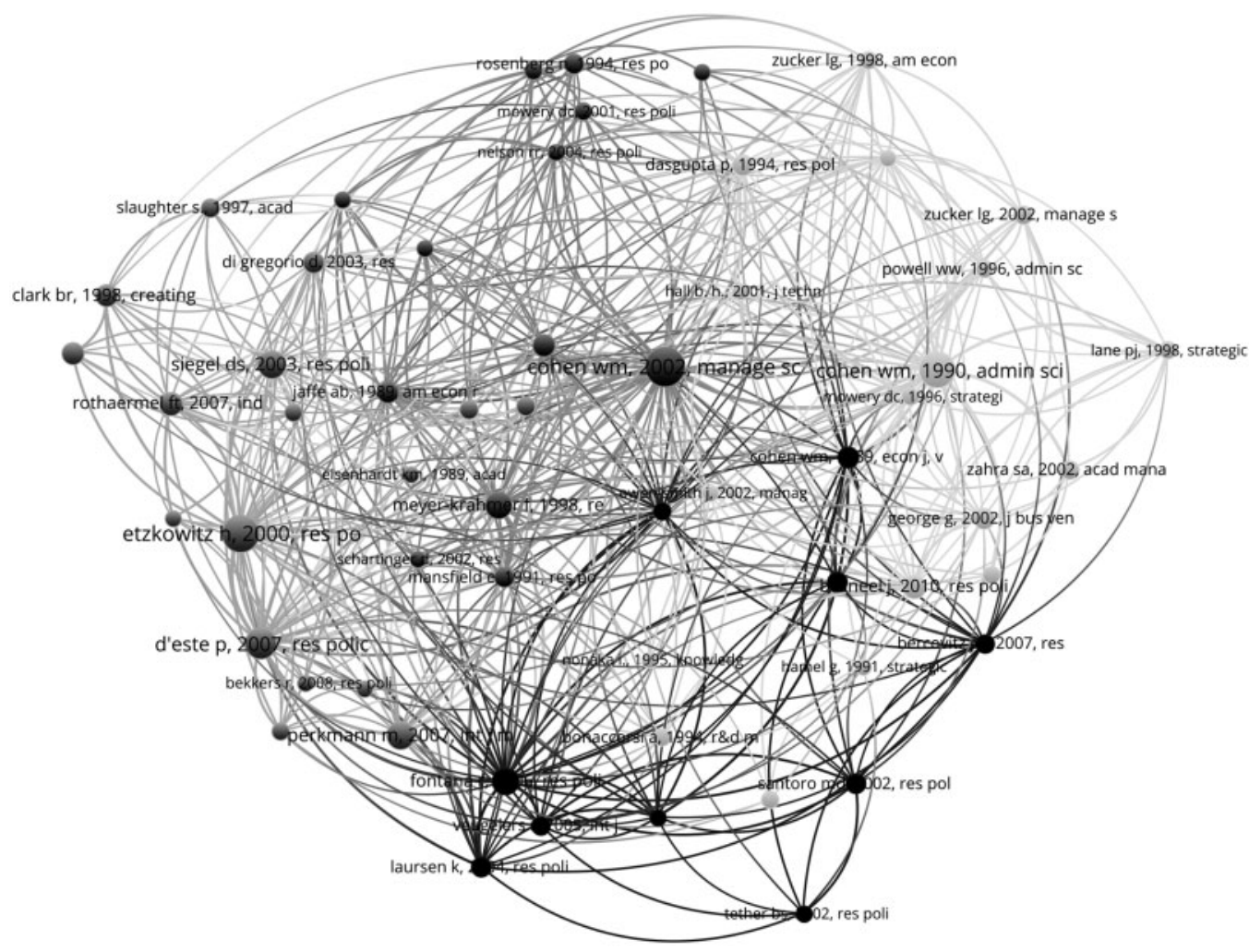

Figure 3. Clusters network.

Table 2. Top five authors of Absorption Capacity, Knowledge and Competitiveness cluster.

\begin{tabular}{|c|c|c|c|c|}
\hline Authors & Article & Journal & Objective & Keyword \\
\hline $\begin{array}{l}\text { Cohen and } \\
\text { Levinthal } \\
1990\end{array}$ & $\begin{array}{l}\text { 'Absorptive Capacity: A New } \\
\text { Perspective on Learning and } \\
\text { Innovation' }\end{array}$ & $\begin{array}{l}\text { Administrative } \\
\text { Science } \\
\text { Quarterly }\end{array}$ & $\begin{array}{l}\text { Study the ability of companies to } \\
\text { recognise the value of external } \\
\text { information, as well as to as- } \\
\text { similate and apply it for busi- } \\
\text { ness purposes, as this is critical } \\
\text { to their innovation capabilities }\end{array}$ & $\begin{array}{l}\text { Absorption capacity, } \\
\text { innovation }\end{array}$ \\
\hline $\begin{array}{l}\text { Bruneel et al. } \\
2010\end{array}$ & $\begin{array}{l}\text { 'Investigating the Factors that } \\
\text { Diminish the Barriers to } \\
\text { University-Industry } \\
\text { Collaboration' }\end{array}$ & Research Policy & $\begin{array}{l}\text { Discover what are the barriers to } \\
\text { university-industry cooper- } \\
\text { ation and ways to overcome } \\
\text { these challenges }\end{array}$ & $\begin{array}{l}\text { University-industry col- } \\
\text { laboration, barriers to } \\
\text { collaboration, inter-or- } \\
\text { ganisational trust }\end{array}$ \\
\hline $\begin{array}{l}\text { George et al. } \\
2002\end{array}$ & $\begin{array}{l}\text { 'The Effects of Business- } \\
\text { University Alliances on } \\
\text { Innovative Output and } \\
\text { Financial Performance: A } \\
\text { Study of Publicly Traded } \\
\text { Biotechnology Companies' }\end{array}$ & $\begin{array}{l}\text { Journal of } \\
\text { Business } \\
\text { Venturing }\end{array}$ & $\begin{array}{l}\text { Examine the potential effects of } \\
\text { links to universities on the in- } \\
\text { novation and performance of } \\
\text { biotechnology companies }\end{array}$ & $\begin{array}{l}\text { University-business } \\
\text { cooperation and } \\
\text { alliances, biotechnol- } \\
\text { ogy, innovation, } \\
\text { knowledge }\end{array}$ \\
\hline $\begin{array}{r}\text { Dasgupta and } \\
\text { David } 1994\end{array}$ & $\begin{array}{l}\text { 'Toward a New Economics of } \\
\text { Science' }\end{array}$ & Research Policy & $\begin{array}{l}\text { Study the formalisation of know- } \\
\text { ledge and its role in R\&D } \\
\text { activities through various sour- } \\
\text { ces of this knowledge and the } \\
\text { dual private and public nature } \\
\text { of technological knowledge }\end{array}$ & $\begin{array}{l}\text { R\&D knowledge, capital, } \\
\text { technological } \\
\text { knowledge }\end{array}$ \\
\hline $\begin{array}{l}\text { Zahra and } \\
\text { George } \\
2002\end{array}$ & $\begin{array}{l}\text { 'Absorptive Capacity: A Review, } \\
\text { Reconceptualisation, and } \\
\text { Extension' }\end{array}$ & $\begin{array}{l}\text { Academy of } \\
\text { Management } \\
\text { Review }\end{array}$ & $\begin{array}{l}\text { Review the literature on the topic } \\
\text { 'absorption capacity' }\end{array}$ & $\begin{array}{l}\text { Absorption capacity, } \\
\text { competitive advantage, } \\
\text { competition, strategic } \\
\text { planning }\end{array}$ \\
\hline
\end{tabular}


Table 3. Top five authors of The Impact of Knowledge Spillovers on University-Industry Cooperation cluster.

\begin{tabular}{|c|c|c|c|c|}
\hline Authors & Article & Journal & Objective & Keyword \\
\hline Cohen et al. 2002 & $\begin{array}{l}\text { 'Links and Impacts: The } \\
\text { Influence of Public Research } \\
\text { on Industrial R\&D' }\end{array}$ & $\begin{array}{l}\text { Management } \\
\text { Science }\end{array}$ & $\begin{array}{l}\text { Study the influence of research done in } \\
\text { universities and public institutes and } \\
\text { research centres }\end{array}$ & $\begin{array}{l}\mathrm{R} \& \mathrm{D} \text {, innovation, } \\
\text { spillovers, start-ups }\end{array}$ \\
\hline $\begin{array}{l}\text { Meyer-Krahmer } \\
\text { and Schmoch } \\
1998\end{array}$ & $\begin{array}{l}\text { 'Science-based Technologies: } \\
\text { University-Industry } \\
\text { Interactions in Four Fields' }\end{array}$ & Research Policy & $\begin{array}{l}\text { Identify the main forms of interactions } \\
\text { between industries and universities, the } \\
\text { advantages and shortcomings of these } \\
\text { interactions from the perspective of } \\
\text { researchers and the specific interests of } \\
\text { industries }\end{array}$ & $\begin{array}{l}\text { Interaction, university- } \\
\text { company, researcher } \\
\text { patents searchers }\end{array}$ \\
\hline $\begin{array}{l}\text { Agrawal and } \\
\text { Henderson } \\
2002\end{array}$ & $\begin{array}{l}\text { 'Putting Patents in Context: } \\
\text { Exploring Knowledge Transfer } \\
\text { from MIT' }\end{array}$ & $\begin{array}{l}\text { Management } \\
\text { Science }\end{array}$ & $\begin{array}{l}\text { Determine the representativeness of patents } \\
\text { in the transfer of knowledge }\end{array}$ & $\begin{array}{l}\text { Patents, knowledge } \\
\text { transfer }\end{array}$ \\
\hline Jaffe 1989 & $\begin{array}{l}\text { 'Real Effects of Academic } \\
\text { Research' }\end{array}$ & $\begin{array}{l}\text { The American } \\
\text { Economic } \\
\text { Review }\end{array}$ & $\begin{array}{l}\text { Examine the contribution of spillovers in } \\
\text { business innovation }\end{array}$ & $\begin{array}{l}\text { Spillovers, patents, uni- } \\
\text { versity research, } \\
\text { innovation }\end{array}$ \\
\hline Mansfield 1991 & $\begin{array}{l}\text { 'Academic Research and } \\
\text { Industrial Innovation' }\end{array}$ & Research Policy & $\begin{array}{l}\text { Find out to what extent technological innov- } \\
\text { ations in various industries have been } \\
\text { based on recent academic research, as } \\
\text { well as the time lags between investment } \\
\text { in recent research projects and the indus- } \\
\text { trial use of results }\end{array}$ & $\begin{array}{l}\text { Technological innov- } \\
\text { ation, product, market } \\
\text { introduction }\end{array}$ \\
\hline
\end{tabular}

Table 4. Top five authors of Strategic Alliances for Business Innovation cluster.

\begin{tabular}{|c|c|c|c|c|}
\hline Authors & Article & Journal & Objective & Keyword \\
\hline $\begin{array}{l}\text { Fontana et al. } \\
2006\end{array}$ & $\begin{array}{c}\text { 'Factors Affecting University-Industry } \\
\text { R\&D Projects: The Importance of } \\
\text { Searching, Screening and Signalling' }\end{array}$ & $\begin{array}{r}\text { Research } \\
\text { Policy }\end{array}$ & $\begin{array}{l}\text { Discover what are the determinants of } \\
\text { cooperation between public research } \\
\text { entities and companies }\end{array}$ & $\begin{array}{l}\text { Public research organisa- } \\
\text { tions, university-com- } \\
\text { pany R\&D, opening }\end{array}$ \\
\hline $\begin{array}{l}\text { Cohen and } \\
\text { Levinthal } 1989\end{array}$ & $\begin{array}{l}\text { 'Innovation and Learning: The Two } \\
\text { Faces of R\&D' }\end{array}$ & $\begin{array}{l}\text { The Economic } \\
\text { Journal }\end{array}$ & $\begin{array}{l}\text { Identify the basic sources of technological } \\
\text { knowledge utilised by firms: firms' own } \\
\text { R\&D, knowledge that originates with } \\
\text { competitors' R\&D spillover and know- } \\
\text { ledge that originates outside industries }\end{array}$ & $\begin{array}{l}\text { Spillovers, knowledge, } \\
\text { R\&D }\end{array}$ \\
\hline Teece 1986 & $\begin{array}{l}\text { 'Profiting from Technological Innovation: } \\
\text { Implications for Integration, } \\
\text { Collaboration, Licensing and Public } \\
\text { Policy' }\end{array}$ & $\begin{array}{r}\text { Research } \\
\text { Policy }\end{array}$ & $\begin{array}{l}\text { Examine the innovation strategies of compa- } \\
\text { nies and their market positioning }\end{array}$ & $\begin{array}{l}\text { Strategy, innovation, } \\
\text { market, innovation }\end{array}$ \\
\hline $\begin{array}{l}\text { Santoro and } \\
\text { Chakrabarti } \\
2002\end{array}$ & $\begin{array}{l}\text { 'Firm Size and Technology Centrality in } \\
\text { Industry-University Interactions' }\end{array}$ & $\begin{array}{r}\text { Research } \\
\text { Policy }\end{array}$ & $\begin{array}{l}\text { Establish how linking to university research } \\
\text { centres can benefit companies by provid- } \\
\text { ing alternatives that facilitate the advance- } \\
\text { ment of knowledge and new technologies }\end{array}$ & $\begin{array}{l}\text { University-industry col- } \\
\text { laboration, technology } \\
\text { transfer, alliances }\end{array}$ \\
\hline $\begin{array}{l}\text { Laursen and } \\
\text { Salter } 2004\end{array}$ & $\begin{array}{l}\text { 'Searching High and Low: What Types of } \\
\text { Firms Use Universities as a Source of } \\
\text { Innovation?' }\end{array}$ & $\begin{array}{r}\text { Research } \\
\text { Policy }\end{array}$ & $\begin{array}{l}\text { Study what factors influence businesses' } \\
\text { demand for university research }\end{array}$ & $\begin{array}{l}\text { Industry innovation, } \\
\text { opening }\end{array}$ \\
\hline
\end{tabular}

guide future trends in this production, as well as its implications for society. The second is a shift from production economies to the socio-economic processes of contemporary innovation systems, with universities becoming part of a new knowledge infrastructure. In the context of current knowledge-based innovation and the associated role played by knowledge-based networks, the model of the university centre as a vehicle for technology transfer has become organisationally and institutionally more complex. Universities now serve as a channel through which the exchange and exploitation of knowledge becomes more effective.

University researchers are now more often involved in cooperation with industries, such as scientific consultancy, contracted research services, or joint research, with fewer patents or spin-offs being registered. D'Este and Patel (2007) found that the individual characteristics of researchers have a stronger impact than the characteristics of their departments or universities. By paying more attention to the wide range of knowledge transfer mechanisms-in addition to patents and spin-offs-policy initiatives can contribute to building the skills needed to integrate scientific research and its applications.

Organisations increasingly rely on external sources of innovation through networked interorganisational relationships. For Perkmann and Walsh (2007), the diffusion and characteristics of collaborative relationships involves two main areas: (1) research processes and correspondence between universities and companies and (2) the organisation and management of collaborative relationships.

The management of those collaborative relationships rely on university TTOs. Siegel et al. (2003) suggest that TTO activities are characterised by constant returns to the scale of the entity in which 
Table 5. Top five authors of university-industry cooperation cluster.

\begin{tabular}{|c|c|c|c|c|}
\hline Authors & Article & Journal & Objective & Keyword \\
\hline $\begin{array}{l}\text { Etzkowitz and } \\
\text { Leydesdorff } \\
2000\end{array}$ & $\begin{array}{l}\text { 'The Dynamics of Innovation: from } \\
\text { National Systems and "Mode2" to a } \\
\text { Triple Helix of University-Industry- } \\
\text { Government Relations' }\end{array}$ & Research Policy & $\begin{array}{l}\text { Examine innovation and univer- } \\
\text { sity-industry links according } \\
\text { to the triple helix model }\end{array}$ & $\begin{array}{l}\text { Triple helix, university- } \\
\text { industry, cooperation }\end{array}$ \\
\hline $\begin{array}{l}\text { D'Este and Patel } \\
2007\end{array}$ & $\begin{array}{l}\text { 'University-Industry Linkages in the UK: } \\
\text { What Are the Factors Underlying the } \\
\text { Variety of Interactions with Industry?' }\end{array}$ & Research Policy & $\begin{array}{l}\text { Identify the types of cooperation } \\
\text { between universities and busi- } \\
\text { nesses and the role of re- } \\
\text { searchers in these }\end{array}$ & $\begin{array}{l}\text { University-industry co- } \\
\text { operation, researcher, } \\
\text { scientific advice, } \\
\text { development contracts }\end{array}$ \\
\hline $\begin{array}{r}\text { Perkmann and } \\
\text { Walsh } 2007\end{array}$ & $\begin{array}{l}\text { 'University-Industry Relationships and } \\
\text { Open Innovation: Towards a Research } \\
\text { Agenda' }\end{array}$ & $\begin{array}{l}\text { International } \\
\text { Journal of } \\
\text { Management } \\
\text { Reviews }\end{array}$ & $\begin{array}{l}\text { Study external sources of innov- } \\
\text { ation and intergovernmental } \\
\text { relations }\end{array}$ & $\begin{array}{l}\text { Inter-organisational rela- } \\
\text { tions, external innov- } \\
\text { ation, open innovation }\end{array}$ \\
\hline Siegel et al. $2003 \mathrm{~b}$ & $\begin{array}{l}\text { 'Assessing the Impact of Organizational } \\
\text { Practices on the Productivity of University } \\
\text { Technology Transfer Offices: An } \\
\text { Exploratory Study' }\end{array}$ & Research Policy & $\begin{array}{l}\text { Assess the activities and licensing } \\
\text { of TTOs }\end{array}$ & TTO, licensing \\
\hline $\begin{array}{l}\text { Rothaermel et al. } \\
2007\end{array}$ & $\begin{array}{l}\text { 'University Entrepreneurship: A Taxonomy } \\
\text { of the Literature' }\end{array}$ & $\begin{array}{l}\text { Industrial and } \\
\text { Corporate } \\
\text { Change }\end{array}$ & $\begin{array}{l}\text { Review the literature on univer- } \\
\text { sity entrepreneurship }\end{array}$ & $\begin{array}{l}\text { University entrepreneur- } \\
\text { ship, TTO, networks } \\
\text { of innovation }\end{array}$ \\
\hline
\end{tabular}

these activities are inserted and that environmental and institutional factors explain part of the variation in performance. Productivity can also depend on organisational practices. The most critical organisational factors are teacher reward systems, TTOs' compensation and personnel practices and cultural barriers between universities and companies.

Rothaermel et al. (2007) conducted an exceptionally comprehensive and detailed literature review of the research on university entrepreneurship, which comprised 173 articles published in various academic journals. Based on this review, the cited authors identified four main lines of research that have emerged in this field of study: (1) university business research, (2) TTOs' productivity, (3) creation of new companies, and (4) environmental contexts including innovation networks.

\section{Final thoughts and future agenda}

In recent decades, the increased demand for innovation and knowledge has led to the reconfiguration of existing research scenarios in order to promote innovative activities (Guerrero et al. 2016). This trend has, in turn, been complemented by academic entrepreneurship. Thus, an entrepreneurial economy creates environments in which its members can exploit opportunities and knowledge to promote entrepreneurial phenomena not envisioned previously (Sam and van der Sijde 2014). Through their mission of cooperation with the business community, universities are no longer considered isolated islands of knowledge but, instead, institutions increasingly involved with a number of external partners through business activities (Zhang et al. 2016a). However, the growing literature on cooperation between universities and industries finds that divergent attitudes between these entities often create major obstacles to more fruitful collaborations (Styhre and Lind 2010; Abreu et al. 2016).

From the present literature review and the clusters obtained from the co-citations of the 294 documents in the sample, we concluded that a strong connection exists between three clusters: Absorption Capacity, Knowledge and Competitiveness in University-Industry Relations; Impact of Knowledge Spillovers on University-Industry
Relations; and University-Industry Cooperation. The Strategic Alliances for Business Innovation cluster distances itself in terms of both number of authors and connectivity to the other clustersincluding co-citations. From these results, we can infer that one of the areas in which much research still needs to be conducted is strategies for innovation. Collaboration between industries and universities faces significant challenges. While universities are driven primarily to create new knowledge and education programmes, private firms focus on acquiring knowledge that can become a competitive advantage (Dasgupta and David 1994). Nonetheless, universities have become increasingly proactive in collaborating with industries, seeking to create valuable intellectual property to promote technology transfer. Therefore, university-industry interactions are being more frequently subjected to measures and management, which has led to more formal contractual exchanges based on codified rules and regulations (Bruneel et al. 2010; Mok 2015).

This brings up the question underlying the present literature review: do university-industry relations constitute an innovation strategy or a research strategy? This review revealed that a mutual strategy exists in university-industry cooperation. However, the literature still shows a gap in regard to this topic. The question remains unanswered of whether this strategy is effective for all stakeholders in this process. The studies that focus on the universities' perspective are few, and the research is based mainly on the type of existing cooperation (Siegel et al. 2003a, 2003b; Perkmann et al. 2013; Urbano and Guerrero 2013).

Another gap appears in what is known about the collaboration between universities and the business community of less developed or peripheral regions. It is also unclear what universities' strategies are in their cooperation with these business communities. Other questions that need to be answered are what the mechanisms of cooperation are and what the outputs of knowledge transfer are to companies in these regions. Thus, the present review revealed several gaps in the subject under study.

This study, as all research does, has its limitations, including those arising from the choice of keywords and the use of only one database. Nonetheless, the present literature review clearly highlights the need for a greater conceptualisation and development of 
the research on areas associated with cooperation between universities and industries.

Thus, with regard to a future research agenda, studies are needed that explore intermediaries, mechanisms, and platforms that can help balance power relations in the context of open innovation within a quadruple helix framework. This will facilitate the transfer of knowledge and ensure its commercialisation is a success (Miller et al. 2016). Future research could focus on the inverse relationship between universities and the surrounding society, which may more accurately capture the economic and social impacts of entrepreneurial universities' activities. Furthermore, researchers need to explore the spillover effect by regions and the indirect effect on this of the global economic crisis (Guerrero et al. 2015). Future studies must also analyse not only how economic growth is influenced by the extent of entrepreneurial universities' activities but also how these activities are influenced by economic growth (Audretsch and Keilbach 2008). All universities cannot be expected to act similarly in relation to cooperation with industries and, thus, to contribute in the same way to economic development. Cooperation between academia and industries depends on the types and structures of the knowledge-exchange processes in which these entities are involved. This, in turn, can facilitate and hinder the use of university knowledge as a competitive asset that encourages the economic growth of competitive and non-competitive regions.

Future studies of entrepreneurial universities and their role in new social and economic landscapes should pay attention to the influence of the characteristics of the regions in which these institutions are located. Researchers need to examine local economic and social contexts to gain a better understanding of the impact and potential of universities (Zhang et al. 2016b). As far as strategic alliances for innovation are concerned, one area of interest would be to analyse more closely how collaborative links develop initially, so future research could focus on the process of partner selection and the way these innovation partnerships function. Finally, a further focus might be the types of interactions that occur within these partnerships (Bruneel et al. 2010; Freitas et al. 2013a; Johnston and Huggins 2016).

\section{Conclusions}

The monetary and social effects of these cooperations are missing on research studies, for instance (Gür et al. 2016; Husgafvel et al. 2017). There is also a need for more studies that examines the external factors that influences the entrepreneurial universities, as for instance the internal, regional, or national facilitating policies (Chang et al. 2016). In Europe, for instance, there is an enormous lack of empirical studies concerning the effects of the new Research Innovations Strategy, imposed by the European Commission (Cunningham and Link 2015).

In conclusion, despite the numerous studies on university-industry cooperation, there is still a wide range of studies that need to be carried out in order to raise awareness of the upstream and downstream aspects of this cooperation.

\section{Funding}

This work is supported by European Structural and Investment Funds in the FEDER component, through the Operational Competitiveness and Internationalization Programme (COMPETE 2020) [Project No. 006971 (UID/SOC/04011); Funding Reference: POCI-01-0145-FEDER-006971]; and national funds, through the
FCT—Portuguese Foundation for Science and Technology under the project UID/SOC/04011/2013.

\section{References}

Abreu, M., Demirel, P., Grinevich, V. et al. (2016) 'The Ivory Tower Approach to Entrepreneurial Linkage: Productivity Changes in University Technology Transfer', Journal of Technology Transfer, 47/2: 268-80.

Agrawal, A. (2001) 'University-to-Industry Knowledge Transfer: Literature Review and Unanswered Questions', International Journal of Management Reviews, 3/4: 285-302.

(2006) 'Engaging the Inventor: Exploring Licensing Strategies for University Inventions and the Role of Latent Knowledge', Strategic Management Journal, 27/1: 63-79.

— and Henderson, R. (2002) 'Putting Patents in Context: Exploring Knowledge Transfer from MIT', Management Science, 48/1: 44-60.

Anderson, A. R., Benavides-Espinosa, M. and Mohedano-Suanes, A. (2011) 'Innovation in Services through Learning in a Joint Venture', Services Industries Journal, 31/12: 2019-32.

Audretsch, D. and Keilbach, B. M. (2008) 'Resolving the Knowledge Paradox: Knowledge-Spillover Entrepreneurship and Economic Growth', Research Policy, 37: 1697-705.

Bekkers, R. and Bodas Freitas, I. M. (2008) 'Analysing Knowledge Transfer Channels between Universities and Industry: To What Degree Do Sectors also Matter?', Research Policy, 37/10: 1837-53.

Bellucci, A., Pennacchio, L., Zou, Y. et al. (2016) 'University Knowledge and Firm Innovation: Evidence from European Countries', The Journal of Technology Transfer, 41/4: 730-52.

Berbegal-Mirabent, J., Sánchez García, J. L. and Ribeiro-Soriano, D. E. (2015) 'UniversityIndustry Partnerships for the Provision of R\&D Services', Journal of Business Research, 68/7: 1407-13. Elsevier Inc.

Bercovitz, J. E. L. and Feldman, M. P. (2007) 'Fishing Upstream: Firm Innovation Strategy and University Research Alliances', Research Policy, 36/7: 930-48.

Boyle, F. and Sherman, D. (2006) 'Scopus: The Product and Its Development', The Serials Librarian, 49/3: 147-53. http://dx.doi.org/10.1300/J123v49n03_12

Bruneel, J., D'Este, P. and Salter, A. (2010) 'Investigating the Factors that Diminish the Barriers to University-Industry Collaboration', Research Policy, 39/7: 858-68.

Carayannis, E. G., Alexander, J. and Ioannidis, A. (2000) 'Leveraging Knowledge, Learning, and Innovation in Forming Strategic GovernmentUniversityIndustry (GUI) R\&D Partnerships in the US, Germany, and France', Technovation, 20/9: 477-88.

Chang, Y. C., Yang, P. Y., Martin, B. R. et al. (2016) 'Entrepreneurial Universities and Research Ambidexterity: A Multilevel Analysis', Technovation, 54: 7-21.

Clark, B. (1998) 'Creating Entrepreneurial Universities: Organizational Pathways of Transformation', Issues in Higher Education, 12/3: 373-4.

Cohen, W. M. and Levinthal, D. A. (1989) 'Innovation and Learning: The Two Faces of R\&D', The Economic Journal, 99/397: 569-96.

Cohen, W. and Levinthal, D. (1990) 'Absorptive Capacity: A New Perspective on Learning and Innovation Wesley M. Cohen; Daniel A. Levinthal Absorptive Capacity: A New Perspective on Learning and Innovation', Science, 35/1: 128-52.

Cohen, W. M., Nelson, R. R. and Walsh, J. P. (2002) 'Links and Impacts: The Influence of Public Research on Industrial R\&D', Management Science, 48/1: 1-23.

Cunningham, J. A. and Link, A. N. (2015) 'Fostering UniversityIndustry $\mathrm{R} \& \mathrm{D}$ Collaborations in European Union Countries', International Entrepreneurship and Management Journal, 11/4: 849-60.

Dasgupta, P. and David, P. A. (1994) 'Toward a New Economics of Science', Research Policy, 23/5: 487-521.

D'Este, P. and Patel, P. (2007) 'UniversityIndustry Linkages in the UK: What Are the Factors Underlying the Variety of Interactions with Industry?', Research Policy, 36/9: 1295-313. 
Doloreux, D. and Mattson, H. (2008) 'To What Extent Do Sectors "Socialize" Innovation Differently? Mapping Cooperative Linkages in Knowledge-Intensive Industries in the Ottawa Region', Industry \& Innovation, 15/4: 351-70.

van Eck, N. J. and Waltman, L. (2010) 'Software Survey: VOSviewer, a Computer Program for Bibliometric Mapping', Scientometrics, 84/2: 523-38.

Enkel, E., Gassmann, O. and Chesbrough, H. (2009) 'Open R\&D and Open Innovation: Exploring the Phenomenon', R\&D Management, 39/4: 311-6.

Estrada, I., Faems, D., Martin Cruz, N. et al. (2016) 'The Role of Interpartner Dissimilarities in Industry-University Alliances: Insights from a Comparative Case Study', Research Policy, 45/10: 2008-22.

Etzkowitz, H. (1983) 'Entrepreneurial Scientists and Entrepreneurial Universities in American Academic Science', Minerva, 21/2-3: 198-233.

- (2002) 'Incubation of Incubators: Innovation as a Triple Helix of University-Industry-Government Networks', Science and Public Policy, 29/2: 115-28.

- (2003) 'Innovation in Innovation: The Triple Helix of University-Industry-Government Relations', Social Science Information, 42/3: 293-337.

— and Klofsten, M. (2005) 'The Innovating Region: Toward a Theory of Knowledge-Based Regional Development', R\&D Management, 35/3: 243-55.

— and Leydesdorff, L. (2000) 'The Dynamics of Innovation: From National Systems and "Mode 2" to a Triple Helix of University-Industry-Government Relations', Research Policy, 29/2: 109-23.

—, Webster, A., Gebhardt, C. et al. (2000) 'The Future of the University and the University of the Future: Evolution of Ivory Tower to Entrepreneurial Paradigm', Research Policy, 29/2: 313-30.

European Commission. (2016) European Research Area Progress Report 2016 Technical Report.

— - (2017) 'Communication from the Commission to the European Parliament, the Council, the European Economic and Social Committee of the Regions: Strengthening Innovation in Europe's Regions: Strategies for resilient, inclusive and sustainable growth'

Fontana, R., Geuna, A. and Matt, M. (2006) 'Factors Affecting UniversityIndustry $\mathrm{R}$ and $\mathrm{D}$ Projects: The Importance of Searching, Screening and Signalling', Research Policy, 35/2: 309-23.

Freitas, I. M., — and Rossi, F. (2013a) 'Finding the Right Partners: Institutional and Personal Modes of Governance of University-Industry Interactions', Research Policy, 42/1: 50-62.

— Marques, R. A. and Silva, E. M. D. P. E. (2013b) 'University-Industry Collaboration and Innovation in Emergent and Mature Industries in New Industrialized Countries', Research Policy, 42/2: 443-53.

Garfield, E. (2001) From Bibliographic Coupling to Co-Citation Analysis via Algorithmic Historio-Bibliography. Philadelphia, PA: Drexel University.

Gasparyan, A. Y., Ayvazyan, L. and Kitas, G. D. (2013) 'Multidisciplinary Bibliographic Databases', Journal of Korean Medical Science, 28/9: 1270-5.

George, G., Zahra, S. A. and Wood, D. R. (2002) 'The Effects of Business-University Alliances on Innovative Output and Financial Performance: A Study of Publicly Traded Biotechnology Companies', Journal of Business Venturing, 17/6: 577-609.

Geuna, A. and Muscio, A. (2009) 'The Governance of University Knowledge Transfer: A Critical Review of the Literature', Minerva, 47/1: 93-114.

Guerrero, M., Cunningham, J. A. and Urbano, D. (2015) 'Economic Impact of Entrepreneurial Universities' Activities: An Exploratory Study of the United Kingdom', Research Policy, 44/3: 748-64.

- Urbano, D., Fayolle, A. et al. (2016) 'Entrepreneurial Universities: Emerging Models in the New Social and Economic Landscape', Small Business Economics, 47/3: 551-63.

Gür, U., Oylumlu, İ. S. and Kunday, Ö. (2016) 'Critical Assessment of Entrepreneurial and Innovative Universities Index of Turkey: Future Directions', Technological Forecasting and Social Change, 123: 161-168.

Hall, J., Matos, S., Bachor, V. et al. (2014) 'Commercializing University Research in Diverse Settings: Moving Beyond Standardized Intellectual Property Management', Research Technology Management, 57/5: 26-34.

Heringa, P. W., Hessels, L. K. and van der Zouwen, M. (2016) 'The Influence of Proximity Dimensions on International Research Collaboration: An
Analysis of European Water Projects', Industry and Innovation, 23/8: 753-72.

Husgafvel, R., Pajunen, N., Dahl, O. et al. (2017) 'Development of Environmental and Economic Sustainability Metrics for the Metal Production Industry-Experiences from University-Industry Cooperation', Frontiers in Sustainability Sustainable Business, Management, and Economics, 2: 98-122.

Jaffe, A. B. (1989) 'Real Effects of Academic Research', The American Economic Review, 79/5: 957-70.

Jiao, H., Zhou, J., Gao, T. et al. (2016) 'The More Interactions the Better? The Moderating Effect of the Interaction between Local Producers and Users of Knowledge on the Relationship between R\&D Investment and Regional Innovation Systems', Technological Forecasting and Social Change, 110: 13-20.

Johnston, A. and Huggins, R. (2016) 'Drivers of University-Industry Links: The Case of Knowledge-Intensive Business Service Firms in Rural Locations', Regional Studies, 50/8: 1330-45.

Kaiser, R. and Prange, H. (2004) 'The Reconfiguration of National Innovation Systems-The Example of German Biotechnology', Research Policy, 33/3: 395-408.

Kim, Y. (2013) 'The Ivory Tower Approach to Entrepreneurial Linkage: Productivity Changes in University Technology Tansfer', Journal of Technology Transfer, 38/2: 180-97.

Laursen, K. and Salter, A. (2004) 'Searching High and Low: What Types of Firms Use Universities as a Source of Innovation?', Research Policy, 33/8: 1201-15.

Lawton Smith, H. and Leydesdorff, L. (2012) 'The Triple Helix in the Context of Global Change: Dynamics and Challenges', SSRN Electronic Journal, 32/4: 1-13.

Leydesdorff, L. and Meyer, M. (2006) 'Triple Helix Indicators of Knowledge-Based Innovation Systems. Introduction to the Special Issue', Research Policy, 35/10: 1441-9.

— Park, H. W. and Lengyel, B. (2014) 'A Routine for Measuring Synergy in University-Industry-Government Relations: Mutual Information as a Triple-Helix and Quadruple-Helix Indicator', Scientometrics, 99/1: 27-35.

Mansfield, E. (1991) 'Academic Research and Industrial Innovation', Research Policy, 20/1: 1-12. Elsevier.

McKeever, E., Anderson, A. and Jack, S. (2014) 'Entrepreneurship and Mutuality: Social Capital in Processes and Practices', Entrepreneurship \& Regional Development, 26/5-6: 453-77.

Meyer-Krahmer, F. and Schmoch, U. (1998) 'Science-Based Technologies: University-Industry Interactions in Four Fields', Research Policy, 27/8: 835-51.

Miller, K., McAdam, R., Moffett, S. et al. (2016) 'Knowledge Transfer in University Quadruple Helix Ecosystems: An Absorptive Capacity Perspective', $R$ \& D Management, 46/2: 383-99.

Mok, K. H. (2015) 'The Quest for Global Competitiveness: Promotion of Innovation and Entrepreneurial Universities in Singapore', Higher Education Policy, 28/1: 91-106.

Muscio, A., Quaglione, D. and Vallanti, G. (2013) 'Does Government Funding Complement or Substitute Private Research Funding to Universities?', Research Policy, 42/1: 63-75.

Ning, L., Wang, F. and Li, J. (2016) 'Urban Innovation, Regional Externalities of Foreign Direct Investment and Industrial Agglomeration: Evidence from Chinese Cities', Research Policy, 45/4: 830-43.

Perianes-Rodriguez, A., Waltman, L. and Van Eck, N. J. (2016) 'Constructing Bibliometric Networks: A Comparison of between Full and Fractional Counting', Journal of Informetrics, 10/4: 1-30.

Perkmann, M., King, Z. and Pavelin, S. (2011) 'Engaging Excellence? Effects of Faculty Quality on University Engagement with Industry', Research Policy, 40/4: 539-52.

—, Tartari, V., McKelvey, M. et al. (2013) 'Academic Engagement and Commercialisation: A Review of the Literature on UniversityIndustry Relations', Research Policy, 42/2: 423-42.

- and Walsh, K. (2007) 'UniversityIndustry Relationships and Open Innovation: towards a Research Agenda', International Journal of Management Reviews, 9/4: 259-80. 
Rampersad, G., Quester, P. and Troshani, I. (2010) 'Managing Innovation Networks: Exploratory Evidence from ICT, Biotechnology and Nanotechnology Networks', Industrial Marketing Management, 39/5: 793-805. Elsevier Inc.

Ranga, M. and Etzkowitz, H. (2013) 'Triple Helix Systems: An Analytical Framework for Innovation Policy and Practice in the Knowledge Society', Industry and Higher Education, 27/4: 237-62.

—, Peralampi, J. and Kansikas, J. (2016) 'The New Face of University-Business Cooperation in Finland', Science and Public Policy, 43/5: 601-12.

Rothaermel, F. T., Agung, S. D. and Jiang, L. (2007) 'University Entrepreneurship: A Taxonomy of the Literature', Industrial and Corporate Change, 16/4: 691-791.

Sam, C. and van der Sijde, P. (2014) 'Understanding the Concept of the Entrepreneurial University from the Perspective of Higher Education Models', Higher Education, 68/6: 891-908.

Santoro, M. D. (2000) 'Success Breeds Succes: The Linkage between Relationship Intensity and Tangible Outcomes in Industry-University Collaborative Ventures', The Journal of High Technology Management Research, 11/2: 255-73.

— and Chakrabarti, A. K. (2002) 'Firm Size and Technology Centrality in Industry-University Interactions', Research Policy, 31/7: 1163-80.

Segarra-Blasco, A. A. and Arauzo-Carod, J.-M. M. (2008) 'Sources of Innovation and Industry-University Interaction: Evidence from Spanish Firms', Research Policy, 37/8: 1283-95.

Shane, S. (2002) 'Selling University Technology: Patterns from MIT', Management Science, 48/1: 122-37.

Siegel, D. S., Waldman, D. A., Atwater, L. E. et al. (2003a) 'Commercial Knowledge Transfers from Universities to Firms: Improving the Effectiveness of UniversityIndustry Collaboration', Journal of High Technology Management Research, 14/1: 111-33.

- Waldman, D. and Link, A. (2003b) 'Assessing the Impact of Organizational Practices on the Relative Productivity of University Technology Transfer Offices: An Exploratory Study', Research Policy, 32/1: 27-48.
Styhre, A. and Lind, F. (2010) 'Balancing Centripetal and Centrifugal Forces in the Entrepreneurial University: A Study of 10 Research Centres in a Technical University', Technology Analysis and Strategic Management, 22/8: 909-24.

Teece, D. J. (1986) 'Profiting from Technological Innovation: Implications for Integration, Collaboration, Licensing and Public Policy', Research Policy, 15/6: 285-305. Elsevier.

Un, C. A.Cuervo-Cazurra, A. and Asakawa, K. (2010) 'R\&D Collaborations and Product Innovation', Journal of Product Innovation Management, 27/5: 673-89.

Urbano, D. and Guerrero, M. (2013) 'Entrepreneurial Universities: Socioeconomic Impacts of Academic Entrepreneurship in a European Region', Economic Development Quarterly, 27/1: 40-55.

Venditti, M., Reale, E. and Leydesdorff, L. (2013) 'Disclosure of University Research to Third Parties: A Non-Market Perspective on an Italian University', Science and Public Policy, 40/6: 792-800.

Veugelers, R. and Cassiman, B. (2005) 'R\&D Cooperation between Firms and Universities: Some Empirical Evidence from Belgian Manufacturing', International Journal of Industrial Organization, 23/5: 355-79.

Waltman, L., van Eck, N. J. and Noyons, E. C. M. (2010) 'A Unified Approach to Mapping and Clustering of Bibliometric Networks', Journal of Informetrics, 4/4: 629-35. Elsevier Ltd.

Zahra, S. A. and George, G. (2002) 'Absorptive Capacity: A Review, Reconceptualization, and Extension', Academy of Management Review, 27/2: 185-203. Academy of Management.

Zhang, Q., Larkin, C., Lucey, B. M. et al. (2016a) 'The Role of the Entrepreneurial University to Improve Innovation in Region', Research Policy, 7/2: 18-25.

-, MacKenzie N. G., Jones-Evans, D. et al. (2016b) 'Leveraging Knowledge as a Competitive Asset? The Intensity, Performance and Structure of Universities' Entrepreneurial Knowledge Exchange Activities at a Regional Level', Small Business Economics, 47/3: 657-75.

Zhou, Y., Li, X., Lema, R. et al. (2016) 'Comparing the Knowledge Bases of Wind Turbine Firms in Asia and Europe: Patent Trajectories, Networks, and Globalisation', Science and Public Policy, 43/4: 476-91. 